\title{
The ecological assessment of the eutrophic biogenic load of the water body
}

\author{
Alena Zhidkova*, Vladimir Podberesnij, and Rimma Zarubina \\ Rostov State University of Economics, Bolshaya Sadovaya st., 69, Rostov-on-Don 344002, Russia
}

\begin{abstract}
The work provides a comprehensive environmental assessment of the eutrophic biogenic load on a water body using the example of the Gulf of Taganrog of the Sea of Azov. This study is carried out with the aim of a deeper understanding of the ecological state of the waters of the Gulf of Taganrog, the processes of its eutrophication. The assessment of the biogenic load on the water area is carried out. The conducted researches showed that the eutrophication of the Gulf of Taganrog northeastern part depends on the salinity, water temperature, ammonium, and nitrate and phosphate concentrations. The level of the internal and external loads of phosphorus in the waters of the Gulf of Taganrog is approximately equal.
\end{abstract}

\section{Introduction}

The work provides a comprehensive environmental assessment of the eutrophic biogenic load on a water body using the example of the Gulf of Taganrog of the Sea of Azov.

Waters eutrophication is a complex process, characterized by the nutrients enrichment, and consequently, the algae number increase. This leads to undesirable changes in the waters quality of the water body, its biological diversity and the disruption of the sustainable water use.

Waters eutrophication is a peculiar phenomenon of the ecosystem, which is achieved by enrichment with nutrients, which, as a rule, stimulates the growth and flowering of algae, and this, in turn, leads to a deterioration in the quality and condition of natural waters. In recent decades, this has become a global environmental problem. Therefore, to develop measures to reduce eutrophication of the water area, first, it is necessary to understand how its processes.

This study is carried out with the aim of a deeper understanding of the ecological state of the waters of the Gulf of Taganrog, the processes of its eutrophication. The assessment of the biogenic load on the water area is carried out.

\section{Materials and methods}

The work was carried out as part of a comprehensive geoecological assessment of the waters of the Gulf of Taganrog from the position of eutrophication. The authors found [1-3] that duribg the study period (from 2002 to 2015), the eutrophication of the waters of the

\footnotetext{
* Corresponding author: soleils@bk.ru
} 
Gulf of Taganrog was primarily influenced by: water temperature, salinity, concentrations of ammonium ion, nitrate and phosphate.

To determine the eutrophic biogenic load on the waters of the Gulf of Taganrog of the Sea of Azov, a comprehensive study was carried out. The research included the following steps:

1. The review and analysis of literature data on the negative impact of eutrophication.

2. The review and analysis of literature data on the hydrodynamics of a water body, temperature conditions, salinity and nutrients

3. The collection and analysis of a database on temperature conditions, salinity and biogenic matter (ammonium ion, nitrate and phosphate).

4. The construction of a mathematical model of the eutrophic change in the waters of the Gulf of Taganrog of the Azov Sea and the calculation of the eutrophic index of the waters.

5. The calculation and analysis of internal and external biogenic loads in the water area.

Besides, an extensive database was used for the study from 2002 to 2015, which included the results of analyzes of seawater samples uncluding the temperature of the water, $\mathrm{pH}$, oxygen, salinity and concentrations of nitrate, ammonium ion and phosphate dissolved in water, obtained during the vegetation period. In general, more than 3000 analysis results had been summarized, 735 original definitions of the content of the biological and hydrological and hydrochemical indicators had been conducted.

First, the waters eutrophic index was calculated to the Gulf of Taganrog of the Sea of Azov [1-3]. The measurements were carried out during the vegetation period (from the beginning of April to the end of October) in 20 sampling sites according to the governmentapproved methods.

A sample of data for a 14-year period from 2002 to 2015, including the average for the vegetative period values of the water temperature, the salinity, the ammonium, nitrate, nitrite and phosphate concentrations and the regression equation, was used to construct the eutrophic index statistical model of the Gulf of Taganrog northeastern part:

$$
T_{\text {stat. }}=k_{0}+k_{1}(S)+k_{2}(t)+k_{3}\left(N_{4}\right)+k_{4}\left(N_{3}\right)+k_{5}\left(P O_{4}\right)+k_{6}\left(N O_{2}\right)+k_{7}(v),
$$

where $T_{\text {stat. }}$ - waters eutrophic index;

$S$ - salinity, \%o;

$t$ - water temperature, ${ }^{0} \mathrm{C}$;

$\mathrm{NH}_{4}$ - ammonium concentration, $\mathrm{mg} / \mathrm{dm}^{3}$;

$\mathrm{NO}_{3}$ - nitrate concentration, $\mathrm{mg} / \mathrm{dm}^{3}$;

$\mathrm{PO}_{4}$ - phosphate concentration, $\mathrm{mg} / \mathrm{dm}^{3}$;

$\mathrm{NO}_{2}-$ nitrite concentration, $\mathrm{mg} / \mathrm{dm}^{3}$;

$v$ - water current speed, $\mathrm{m} / \mathrm{s}$;

$k$-empirical coefficients.

Next, the general load on the water body is calculated:

$$
J g=(J e)+(J i)
$$

where $J g$ is the general load on the water body,

$J e$ - the external load;

$J i$ - the internal load.

The external load on the water area is a complex of the particular external loads, represented in the form of the following mathematical model [4]:

$$
J e=(J w)+(J d . s .)+(J f . r .)+(J r)+(J r . r),
$$

where $J e$ is the total load, t/year;

$J w$ - the load supplied respectively with wastewater, t/year; 
Jd.s. - the load from the diffuse sources, $\mathrm{t} /$ year;

$J f . r$. - the load from the flat drain, $\mathrm{t} /$ year;

$J r$ - the load from the recreation, $\mathrm{t} /$ year;

$J r . r$. - the load from the river runoff, $\mathrm{t} /$ year.

To calculate the internal nitrogen load on the waters of the Gulf of Taganrog of the Sea of Azov, the method developed by E. Neverova-Dziopak was used [4]. This method is based on constructed the mathematical dependence of the nitrogen flux from the bottom sediments into water on the weight ratio of the concentration of the organic carbon to nitrogen concentration:

$$
J_{N}=122.5-7,82 \cdot x,
$$

where $J_{N}$ is the nitrogen flux from the bottom sediments, $\mathrm{mgN} / \mathrm{m}^{2}$.day;

$x$ is the concentration of the organic carbon to the concentration of nitrogen $\mathrm{C} / \mathrm{N}$.

Concentration of nitrogen and phosphorus in the pore solution of the bottom sediments are defined by the mineralization speed of the organic substances in the bottom sediments. When concentration of matter in natural waters is 1-2 and more orders lower, than in steam solution, the concentration gradient can be accepted equal in size of concentration of substance in the pore solution.

Phosphorus of the bottom sediments. The accumulation of phosphorus in the bot-tom sediments happens both in the organic, and in the mineral forms, and from 40 to $80 \%$ of the organic phosphorus getting to the reservoir is mineralized.

\section{Results}

Based on the database of the long-term averages during the vegetation period of in the Gulf of Taganrog northeastern part, the regression equation was obtained:

$$
T_{\text {stat }}=6.294+0.104(\mathrm{~S})+0.114(\mathrm{t})-1.06\left(\mathrm{NH}_{4}\right)+0.021\left(\mathrm{NO}_{3}\right)-0.929\left(\mathrm{PO}_{4}\right) .
$$

The validity of the regression equation showed the following results:

- the correlation coefficient -0.822 ;

- the determination coefficient R2 - 0.676;

- the standard error -0.205 ;

- F-test - 22.13;

- Student's t-test for salinity is 3.11, for temperature 9.38, for ammonium 2.95, for nitrate 3.61, for phosphate 2.09. The table value is 2.00 [5]. Thus, all the coefficients of the regression equation are statistically significant.

The conducted researches showed that the eutrophication of the Gulf of Taganrog northeastern part depends on the salinity, water temperature, ammonium, and nitrate and phosphate concentrations.

The investigated water area feature is the shallowness, almost complete absence of the current, predominance of the overtaking currents, the stratification absence. The eutrophic index fluctuations are mostly affected by the water temperature changes, which are in agreement with the other literature data [5-8].

So, long-term fluctuations of the nutrients content in the Gulf of Taganrog northeastern part waters significantly depend on the river runoff defining dynamics of the waters, and also substantially from the water temperature changes and wind activity. Researches showed that:

A) The phosphate concentrations changed from $0.004 \mathrm{mg} / \mathrm{dm}^{3}$ to $0.905 \mathrm{mg} / \mathrm{dm}^{3}$, the average $-0.072 \mathrm{mg} / \mathrm{dm}^{3}$.

B) The ammonium concentrations changed from $0.016 \mathrm{mg} / \mathrm{dm}^{3}$ to $1.255 \mathrm{mg} / \mathrm{dm}^{3}$, the average $-0.109 \mathrm{mg} / \mathrm{dm}^{3}$. 
C) The nitrite concentrations changed from $0.001 \mathrm{mg} / \mathrm{dm}^{3}$ to $0.508 \mathrm{mg} / \mathrm{dm}^{3}$, the average $-0.010 \mathrm{mg} / \mathrm{dm}^{3}$.

D) The nitrate concentrations changed from $0.01 \mathrm{mg} / \mathrm{dm}^{3}$ to $14.280 \mathrm{mg} / \mathrm{dm}^{3}$, the average $-1.380 \mathrm{mg} / \mathrm{dm}^{3}$.

The studies showed that for the waters of the Gulf of Taganrog, the external load for phosphorus was 4.580 tons / year, for nitrogen -25.559 tons / year. The calculation of each of the represented external loads for the waters of the Gulf of Taganrog was carried out by the authors earlier [1-3]. The total external load for phosphates was 14.050 tons / year, for nitrates -40.012 tons / year, for ammonium ion -21.256 tons / year.

The greatest phosphate wastewater load was in 2002 (68.048 t / year), the lowest one was in 2006 (32.706 t/ year). The greatest nitrate load was in 2002 (2204.606 $t$ / year), the lowest one was in 2004 (444.86 t / year). This is directly related to the total volume of the wastewater dumped in the Gulf and their level of purification.

Nevertheless, the greatest part of the biogenic matter is receiving to the Gulf with the river runoff, which is the runoff of the River Don. The concentration of the biogenic matter in the delta remains at a high level in recent years. Based on the analysis, we can conclude that the external load on the Gulf of Taganrog of the Sea of Azov is $99 \%$ determined by the River Don flow and wastewater.

The mean annual concentration of carbon and nitrogen in the water of the Gulf of Taganrog: $\mathrm{C}=0.348 \mathrm{mg} / \mathrm{l} ; \mathrm{N}=0.062 \mathrm{mg} / \mathrm{l}$. The water area square is $5300 \mathrm{~km}^{2}$. Then the internal load of nitrogen of the studied water area is $75.58 \mathrm{mg} \cdot \mathrm{N} / \mathrm{m}^{2} \cdot$ day.

The average volume weight of the bottom sediments is about $1.5 \mathrm{t} / \mathrm{m}^{3}$ [5].

Thus, at average size $1700 \mathrm{mg} \cdot \mathrm{N} / \mathrm{m}^{2}$. day the internal load of nitrogen for the Gulf of Taganrog is $67.700 \mathrm{t} / \mathrm{year}$.

The estimation of the flux of phosphorus from the bottom sediments of the waters of the Gulf of Taganrog is based on the following assumptions:

- the processes of chemisorption of the mineralized phosphorus were not taken into account; the source of phosphate is only organic phosphorus;

- the phosphatification process is described by the exponential dependence;

- the constant of phosphatification rate is taken equal to 0.018 days $^{-1}$ [5];

- the volume of the pore solution is equal to the volume of the active layer of deposits, equal to $2 \mathrm{~cm}$ in thickness, as for nitrogen $-10.6 \cdot 10^{6} \mathrm{~m}^{3}$;

- the concentration gradient of phosphate is equal to the concentration in the pore solution;

- the diffusion coefficient is taken equal to $0.93 \cdot 10^{-6} \mathrm{~cm}^{2} / \mathrm{s}$ [5].

Accordingly, the internal phosphorus load for the water area is $4.930 \mathrm{t} /$ year.

The internal and external loads of nitrogen and phosphorus make it possible to estimate the general load of the biogenic matter on the waters of the Gulf of Taganrog: $93.259 \mathrm{t} / \mathrm{year}$ - for nitrogen; $9.510 \mathrm{t} / \mathrm{year}$ - for phosphorus.

The level of the internal and external loads of phosphorus in the waters of the Gulf of Taganrog is approximately equal. The internal nitrogen load is 2.5 times higher than the external one, which indicates a significant accumulation of nitrogen-containing compounds in the bottom sediments of the water area.

Consequently, The Gulf of Taganrog is the water object of the mesotrophic type, which turns into the eutrophic one. The mail reasons for such a high eutrophication level are: the huge general load of nitrogen and phosphorus, high water temperatures in summer period, shallowness of the studied water body and its salinity. 


\section{Conclusion}

The Gulf of Taganrog is the top of this water body. In particular, to this area of the water area the Don River and its tributaries runoff flows. The studied water body is the shallowest part of the Gulf of Taganrog, has no pronounced flow, which is circular and overtaking.

During the study period, the mean values of the water area salinity vary from 1 to $5 \%$ for the vegetation period. In the period from 2002 to 2010, there was the decrease in salinity to $0.8-1.5 \%$, and in the period from 2011 to 2015 - the increase. This trend is explained by the fact that the salinity of the Gulf of Taganrog northeastern part waters is regulated mainly by the Don River runoff.

The most characteristic feature is the strong dependence of the temperature field on solar and thermal radiation in the entire water mass. The modern data analysis showed that the average temperature during the vegetation period for the Gulf of Taganrog northeastern part waters in recent years does not differ significantly and is maintained at the level of 14.5-22.2 ${ }^{\circ} \mathrm{C}$.

During the warm season, this part of the studied water area is subject to the active eutrophication. In this regard the statistical model of the eutrophic index definition on the example of the Gulf of Taganrog of the Sea of Azov is developed.

Taking into account that the square of the Gulf of Taganrog of the Sea of Azov is 5300 $\mathrm{km}^{2}$, the annual average concentrations of phosphorus and nitrogen are $0.348 \mathrm{mg} / \mathrm{l}$ and $0.062 \mathrm{mg} / \mathrm{l}$. The external load on the Gulf of Taganrog of the Sea of Azov is $99 \%$ determined by the runoff of the River Don and wastewater. The external load for phosphorus was $4.580 \mathrm{t}$ /year, the nitrogen one was $25.559 \mathrm{t} /$ year. The diffuse nitrogen flux from the bottom sediments was $35 \mathrm{mg} \cdot \mathrm{N} / \mathrm{m}^{2} \cdot$ day. The value of the internal nitrogen load was $67700 \mathrm{t} /$ year. The value of the internal phosphorus load amounted to 4930 thousand t/year. The general load for nitrogen was 93259 t/year. The general load for phosphorus was $9510 \mathrm{t} /$ year.

As a result, The Gulf of Taganrog is the water object of the mesotrophic type, which turns into the eutrophic one. The mail reasons for such a high eutrophication level are the huge general load of nitrogen and phosphorus, high water temperatures in summer period, shallowness of the studied water body and its salinity.

\section{References}

1. A. Yu. Zhidkova, N. V. Gusakova Development of the mod-el for determining of the trophic status of shallow-water reservoir, Advanced Materials Research v. 838-841, pp. 2578-2581 (2014).

2. A. Yu. Zhidkova, V. V. Petrov, N. V. Gusakova The Research of Waters Eutrophication of the Gulf of Taganrog of the Sea of Azov For Ecological Monitoring Purposes Exploration and Monitoring of the Shelf Underwater Environment Edited by Iftikhar B. Abbasov, Wiley-Scrivener 318 p. (2018).

3. A. Yu. Zhidkova, N. V. Gusakova Assessment of the total load on the water area of the Taganrog Bay, Natural and technical sciences v. 11, pp. 148-153 (2017).

4. E. V. Neverova-Dziopak Theoretical, methodological and engineering support of the surface waters protection from the anthropogenic eutrophication: doctoral thesis (SPb) 345p (2003).

5. G.G. Matishov, O.V. Stepanyan, K.S. Grigorenko, V.M. Kharkovsky, V.V. Povazhniy, V.G. Sawyer Features of the hydrological and hydro chemical regime of the Azov and Black Seas in 2013, Bulletin of the Southern Science Center v. 11 (2), pp. 36-44 (2015). 
6. A.I.Sukhinov, A.V. Nikitina, D.S. Khachunts, A.E. Chistyakov Mathematical modeling of spatially heterogeneous hydrobiological processes in the Sea of Azov, Monograph, 172 p. (2016).

7. G. G. Matishov, S.V. Gargopa, S.V. Berdnikov, S.L. Dzhenyuk Regularities of ecosystem processes in the Sea of Azov (Prod. SSC Russian Academy of Sciences center Moscow) pp 13-34 (2006).

8. G.G. Matishov, Yu. A. Zhdanov, N.V. Lebedeva, D.G. Matishov, Yu. A. Fedorov, S.V. Berdnikov,V.N. Dumbay, A.D. Chinarina Ecosystem researches of the Sea of Azov and the coast, KSC Russian Academy of Sciences, v. IV, 94 p. (2002). 